\title{
4. 気液および気液固反応装置*
}

本䅧においては“液系の反応工学” とついてのレビュ 一（本誌 30，No.6 (1966)) 以降化発表された気夜・気

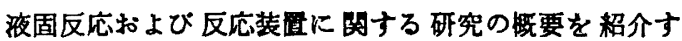
る。気液系反应とガス吸収とは密接に関係しているか， ここでは主として反応工学的钼点から行なわれた研究を 取扱い，反応吸収に関しては本誌のレビュー（33，No. 8 (1969)) を参照されたい。最近，気泡に関係する基礎 的研究か活発傜行なわれているか，本稿ではその一部し か稆介できなかった。詳細については Tavlarides ら ${ }^{182)}$ および Calderbank ${ }^{23)}$ の総説を参照されたい。また管内

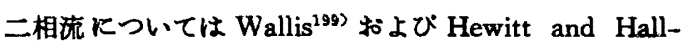
Taylor ${ }^{63)}$ の成書ならびに Rhodes and Scott ${ }^{150)}$ の編書 が刊行されている。

\section{1. 条流・気洨固反応の総括反応這度}

\section{$1 \cdot 1$ 気液反度}

気花反応，反分吸収理論に関しては、レビュー8,211), 総説 ${ }^{17,35,48,130)}$ おび成基9,31) がすでに発表されている。

山口ら ${ }^{208)}$ はガスについて1次, 液についてn次の不 可逆反応の律速段階について詳細に愉討している。大竹 ら ${ }^{136)}$ はガス，液成分についてそれぞれ1次および0次 の不可逆反応を伴5気液反応の粉括反応速度をガス境膜 抵抗や液量の影繁を考虑して解析し，その結果を気泡塔

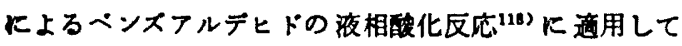

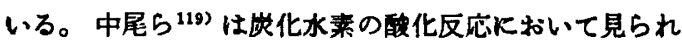
る新雜な反応速度式をるつ場合の反応吸収に対する近似 解法を提出している。宮内ら ${ }^{115)}$ は $C_{11}$ フルフォオレフ ィン（AO）をコーテンクした球の充虽層に $\mathrm{SO}_{3}$ ガスを ハルス状に送り，その応答を一次元拗散モデルと反応吸 収理論に基ついて解析し， $\mathrm{AO}$ と $\mathrm{SO}_{3}$ の反应速度を求 めている。

境膜内反応が無視できる遅い気夜反応を取扱った研究 Кはつぎのるのがある。Daté ら

- 昭和 47 年 5 月 6 日受理

** Kenji Hashimoto (正会员) 宗都大学工学部 化学工学科

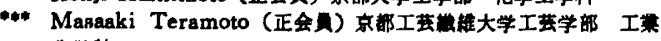
化学科

\section{橋 本 健 治**. 寺 本 正 明***}

ルおよびその 混合物の hydrochlorination の速度定数を 均相法で決定し，その結果を半回分擋拌槽に適用してい る。Silberstein $5^{1711}$ はベンぜンの逐次塩素化について 同様な研究を行ない，この反応系を用いて液相物質移 動係数 $k_{L}$ 户気液界面積 $a$ を求める方法を提出してい $3^{170)}$ 。传藤ら ${ }^{158)}$ は流通式自由表面擋拌槽を用いてエチ レンと酢酸第二水銀との反応速度定数を决定している。

Balasubramanian $5^{10)}$ は擋拌槽を用いて $\mathrm{C}_{2} \mathrm{H}_{4} \mathrm{Cl}_{2}$ 液 中への $\mathrm{C}_{2} \mathrm{H}_{4}$ と $\mathrm{Cl}_{2}$ の同時吸収実験を行ない, $\mathrm{C}_{2} \mathrm{H}_{4} \mathrm{Cl}_{2}$ の生成速度が境膜説に基つく不可逆瞬間反応を伴らガス 吸収理論とよく一致することを示している。Desai ら ${ }^{37}$ は $\mathrm{Cl}_{2}$ を客存する $\mathrm{C}_{2} \mathrm{H}_{2} \mathrm{Cl}_{4}$ 液中への $\mathrm{C}_{2} \mathrm{H}_{2}$ の吸収実跧を 行ない, $\mathrm{C}_{2} \mathrm{H}_{2} \mathrm{Cl}_{4}$ の生成速度が $\mathrm{Gal}-\mathrm{Or} 5^{50)}$ の反応吸収 モデルK基つく計算值と比慗的よく一致すると報告して いる。その他，気液反応の総括反応速度に関する報告と しては、 $\mathrm{Cl}_{2}$ を容存する水中への $\mathrm{C}_{2} \mathrm{H}_{4}$ の反応吸収による $\mathrm{ClC}_{2} \mathrm{H}_{4} \mathrm{OH}$ の生成反応 ${ }^{3}$, ヘヘンズルルデドの液相酸 化 $^{117,120.121)}$ ，アセトアルデヒドの夜相酸化 ${ }^{184) ， シ ク ロ ~}$ ヘキサノールの酸化"1)，一キストーワッカー法によるフ

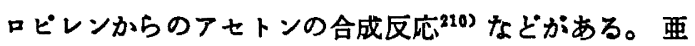
硫酸ソーダの空気酸化速度についても多数報告されてお $\eta^{11,98,101,128,175,204)}$ ，垔硫酸アンモ二ウムの酸化 ${ }^{110)}$, $\mathrm{H}_{2} \mathrm{SO}$ 、水溶液によるインブンンンの吸収 ${ }^{54}, \mathrm{Na}_{2} \mathrm{~S}_{2} \mathrm{O}_{4}$ の

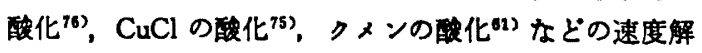
析す行なわれている。

気液系複合反応の選択性に咸する研究す取近かなり報 告されている。 van de Vusse ${ }^{191}$ は気液逐次反応の中間 生成物の収率を境膜説に基ついて解析し，Thiele 数に 相当する因子，液とガスの瀑度比などの操作因子が選択

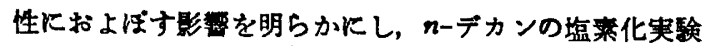
により理論を検討している。井上ら は3 は拼拌槽による Pークレソールの逐次塩案化反応を表面更新 モデルによ り解析している。橋本ら ${ }^{58}$ ，寺本ら ${ }^{\text {(83) }}$ は境膜説に基つ いて逐次反应における出発物筫の反応事之中間生成物の 収率との関係および反応率之時間の関係を解析し, 自由

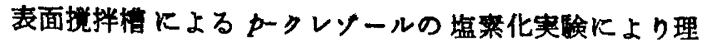
論の有用性を立証している。さらに気泡塔および通気摚 拌槽による実験を行ない，塩素の気泡径が選択性を支配 
する重要な因子であり，摚拌強度の影飄はないことを見 出している ${ }^{184}$ 。 Harriott ${ }^{57)}$ は浸透説に基つく単一反応 を伴らガス吸収理論を用いて中間生成物の收率を計算す る簡便法を提出している。Bridgwater $5^{16,180)}$ は中間生 成物の放散が無視できない場合を取报っている。van de Vusse ${ }^{192)}$ および大木ら ${ }^{125)}$ は反応装置内における流体の 混合侎式と選択性との関係について論じている。

\section{1 .2 気洨固反忘}

愁濁触媒を用いる気液固反応の律速段階な゙よ゙総括反 応速度と操作条件との関係については主に捝拌槽におい

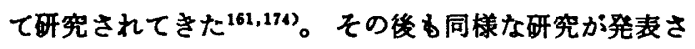

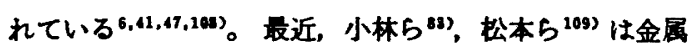
触媒の担持臬を变化させて多孔性蝶媒の有効保数》を推 定し，微媒においてるクの值はかなり小さいことを 示した。Satterfield ら ${ }^{1599}$ はのーメチルスチレン (AMS) の水添速度を粉末および成型触某について溉定して有効 係数を求めている。Sherwood $5^{105)}$ 忙愁渴気泡塔を用 いて，3種類の 反応の律速段階について論している。 Kölbel (6) $^{(6)}$ はラー蚛媒による $n$-dodecene-1 の水添反 応を気泡塔で行ない，Langmuir 型の速度式を得て，さ らに物質移動過程を考虑して反応器性能を娭討してい ろ。Calderbank $5^{20)}$ は気液间物筫移動と蜰媒表面反応 を考虑して得た式を一部正することにより絲沟気泡塔 に抽り Fischer-Tropsch 反応のデータを整理してい る。

Satterfield ら ${ }^{160)}$ は灌液反底器のモデルとして触媒を 連珠状につるした反応器を用いて，AMSの水添反応㮩 対する物質移動の影要を考察している。清水ら ${ }^{1671}$ は灌 液反応器に上る重油の水添脱硫反応を物啠移動過程を考

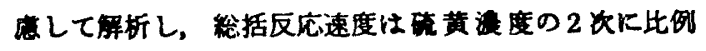
し, 触媒粒子（直径 $d_{p}=0.8 \mathrm{~mm}$ ) 内の反庀が律速であ ると推定している。加藤ら ${ }^{79}$ 忡内部循棵型の流通反応器 に上る水添脱硫実験から，反底次数は硫黄港度につを 2 次，水秦王について1次であり， $d_{p}=1 \mathrm{~mm}$ 以下では粒 内払散抵抗は無視できると報告している。

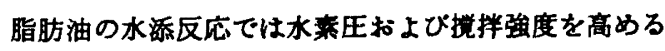
と，中間生成物の収率が低下することが知られている”。 橋本らは第 1 段および第 2 段の反応速度の水菜圧侬存性 がそれぞれ 1次と $1 / 2$ 次であることを確かめ59)，つぎ

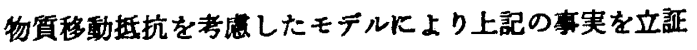
しだ0)。Coenen ら 292 は多孔性媒の細孔分布か脂肪油 の水添反応の選択性飞影签すると報告しており, Sch68n $5^{163)}$ は本反応対与る速度論的研究, 摚拌槽型反応器

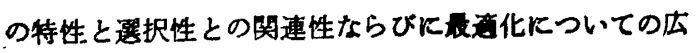
筑囲な研究を発表している。

\section{2. 気液・気液固反応装是とその設幛}

\section{$2 \cdot 1$ 工業反応装是}

現在，工業的に使用されている気液・気液固反応装置 としては，1）擋拌槽，2）気泡塔，3）充埙層，4）三相 流動層 (気液系流動層)，5）移動層，6）管型反応器な どがあげられる。

渡会200) は工業的飞実施されている気液接触反応を列 記し, 反応器形式，操作条件，触媒などを表にまとめ, さらに各種の反応器の特徽と問題点について論じてい る。Østergaard ${ }^{132)}$ は石油留分の水添脱硫, Fischer-Tro psch 反応などの気液固反応操作について概説している。 Prengle ${ }^{\mathbf{1 B} 3}$ は各種の液相酸化反応ブセスの概要を解説 し, 反応の多くは気夜間の物質移動過程が律速になって いると述べている。

石油留分の水菜化脱硫装展としては下向並流充埧層が 多く採用されているが'190)，上向並流型の流通方式す可 能であり，後者が脱硫率において優れているとの報告す ある。しかし島田ら ${ }^{166)}$ の実験では流通方式による明確 な差異は認められていない。重質油の水添脱硫を充填層 で行ならと油飞含まれている重金属類が繦媒表面に析出 し，触媒活性の低下と充埧層の目づまりを起こす。これ に対し三相流動層を用いる H-Oil 法では操業中に触媒 の排出と補給が可能であり，触媒活性を一定水淮に保持 できる利点を持つ ${ }^{1811}$ 。最近，加藤ら ${ }^{78)}$ は触媒を放しく 流動化させずに移動㬝の形式にすると夜の混合が抑制さ れて脱硫率が向上し，さらに装膡下部から劣化触媒の排 出が可能であると報告している。

Pruden 5 ${ }^{141)}$ は管型反応器下部からガスを吹込み，そ

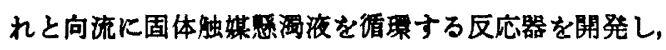
この形式を採用すれば普通の慜濁気泡塔と比較してガス ホールドフッブが增大し、収率す增加すると述べてい る。製紙工莱で浸出唷として使用される Calcium bisulfite acid は $\mathrm{SO}_{2}$ 、水, $\mathrm{CaCO}_{3}$ との間の非触媒三相反応浽 より製造されるか，Volpicelli ら ${ }^{197)}$ は従来から使用さ れている灌夜充埧荅よりす三相流動首を採用する方が有 利になると報告している。

\section{$2 \cdot 2$ 反応装而設什}

気液・気液固反応器は多相流反応器であって，単相流 に比較してその流動状態は非常に䙓㒕であり，その上に 各相間の物筫・熱移動を考虑せねばならず，現象を忠実 に把握した設計理論を確立することは非常に，困難であ る。現在採用されている简単な設計法は，各相の流れを 理想化して完全混合あるいはピストン流れと近似する方 法である。Russell ら 26,27, 102) は気泡の举動に注目して, 擋择槽, 気泡塔および管型反応器の設計にこの近似法を 探用し，設計に必要な装湿の特性値の算出法を解説して 
いる。小出ら ${ }^{811}$ は反応吸収理論を基礎にして境膜内反応 を考虑した設計式を提出している。Fair(1)は気泡塔の 具体的設計法につき, Prengle ら $^{1399}$ は液相酸化反応の速 度論的取扱いと気泡塔, 擋拌槽反応器 の設計法につい て，それぞれ解説している。さらに Pavlica ら ${ }^{137)}$, Kölbel ら ${ }^{883}$ 法軸方向の混合厸散係数を考虑した設計理論を展開 している。Wöhler ら ${ }^{207)}$ はシシテン (ガス) の塩酸水 㴼夜中での加水分解反応実臨を行ない，液泥合の装圈容

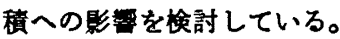

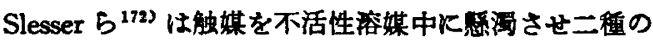
ガスを吹込む Fischer-Tropsch 型反応に対する简単な設 計法を提出している。甲 (stergaard ${ }^{\text {(32) }}$ は払散モデル型の 設計式を提案しているか，触媒浱度の軸方向分布につい ては考虙していない。Kölbel ら"1゙はチレンの水添反 応をモデル反応に選び，総括反応速度および装䧳特性值 を测定しフフナログ計算機を用いて䋝濁気泡塔の反応成 蒙をシミュレートしている。

\section{3. 気液・氛洨固反度装而の特性}

\section{$3 \cdot 1$ 通究瀵拌棈}

通気摫拌槽の諸特性に関しては多くの総説 $21,64,65,148$, 169,193) があるので，ここではそれ以後の研究を中心にし て稆介する。捝拌棤における固夜間物質移動については 永田 ${ }^{116)}$ の棇説および Satterfield ${ }^{161)}$ の成書を参照された い。

（1）気液界面積・ホールドフッフ Linek ら 97 は反応器内でのガス吸収速度の気液界面皘 $a$ おびガス

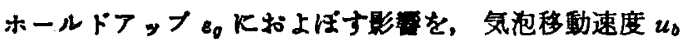
かi $d_{0} n\left(d_{0}=\right.$ 気泡径， $n$ =定数）K比例するとしたモデル 火基ついて解析し，その妥当性を $\mathrm{O}_{2}-\mathrm{Na}_{2} \mathrm{SO}_{3}$ 水溶液系 （Co触媒）の実稌に上り立証した。西解筫容夜中では水

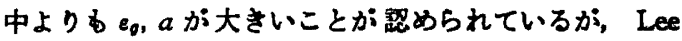
$5^{913}$ は $\mathrm{NaCl}$ および $\mathrm{Na}_{2} \mathrm{SO}$ ，水楁夜一空気系で $\varepsilon_{0}$ と $a$ を 测定し，一定摚拌条件下での $\varepsilon_{0}$ と $a$ は，合一する前の

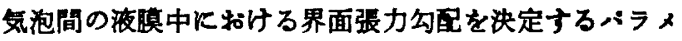
一夕 $c_{0}(d \sigma / d c)^{2} \cdot \phi K よ っ て$ 電解質の種類を問わずに相

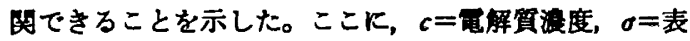
面㖘力, $f=$ 活量度係数, $\phi=[1+d \ln f / d \ln c]^{-1}$, 添字 $\theta=$ 液本体である。彼等はさらに Marrucci ら ${ }^{1011}$ に上る気 泡塔のテータる同じバラメータで相関できると報告して いる。Kawecki ら ${ }^{\text {(1) }}$ は翼近傍での気泡径分布が Erlang

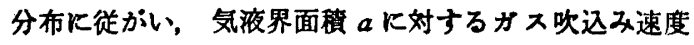

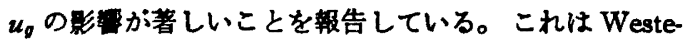
rterp 5 205) の実跧結果とは異なっている。其先端から

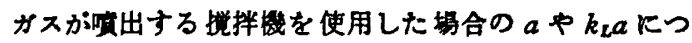
いては Zlokanik ${ }^{213)}$ の報告がある。また, $\mathrm{Na}_{2} \mathrm{SO}_{3}$ 水溶
液一 $\mathrm{O}_{2}$ 系を用いた反応吸収法によりaを求めた De Waal $5^{38}$, Linek ら ${ }^{96)}$ の報告, $\mathrm{CuCl}_{2}, \mathrm{FeCl}_{3}$ およびごく微量 の $\mathrm{PdCl}_{3}$ を含む水溶夜中での $\mathrm{CO}$ の液相醀化反応 ${ }^{72}$ を 利用して $a$ や $k_{L}$ を測定した今中ら ${ }^{72)}$ の研究がある。

(2) 物質移動 Gal-Or $5^{50)}$ は擋拌槽内の気液間 物質移動を境膜浸透説的なモデルにより解析し, Cooper $ら^{30)}$ の実験結果とモデルKよる計算值を比較してい

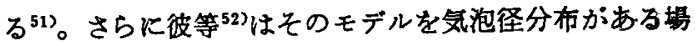
合に拡張し，速い不可逆 1 次反応を伴う場合の吸収速度 は，単に Sauter 径を気泡群の代表径とした场合の吸収 速度で精度よく近似できることを示した。Gal-Or ら は気泡径分布や滞留時間分布をるつ分散系の物質移動の 解析方法についてる報告している。

Calderbank ら ${ }^{199}$ によれば気泡-液間の物質移動係数 $k_{L}$ は気泡径に上り支配され，大気泡城 $\left(d_{0}>2.3 \mathrm{~mm}\right)$ では $k_{L}$ 壮大きく， $k_{L} \propto D^{1 / 2}$ (浸透説) であり，小気泡 域 $\left(d_{b}<0.6 \mathrm{~mm}\right)$ では $k_{L}$ は小さく, $k_{L} \propto D^{2 / 3}$ (境界屏

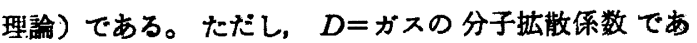
る。これに対して, Linek ら ${ }^{999}$ は䉓解質溶液では気泡 は大気泡域にあるにすかかわらず $k_{L}$ は $D^{2 / 3}$ 飞比例する ことを見出し，これより電解質水溶液では界面における 物理化学的, 電気的性筫が物質移動に影響をおよぼし, Calderbank らの概念は適用できないるのと推論した。 さらK Linek 5 ${ }^{1002}$ は $\mathrm{O}_{2}-\mathrm{Na}_{2} \mathrm{SO}_{3}$ 水溶液系で実測した $k_{L}$ の值より，King ${ }^{82)}$ の物質移動モデルに含まれるバラ メータを算出し， $k_{L}$ を $\mathrm{Na}_{3} \mathrm{SO}_{3}$ 瀑度と所要動力とを用 いて相関している。吉田ら ${ }^{212)}$ は自由液面搅拌槽を用い て加压下で水扰よび $\mathrm{KCl}$ 水客液中への $\mathrm{O}_{2}$ 吸収実跧を行 ない，数気圧以上では $k_{L}$ 江圧の增大とともに減少する ことを認め，その原因は厌に上る表面張力の変化に上る と推察している。その他，客液の粘度，イオン強度を含

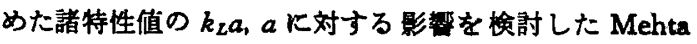
ら ${ }^{122)}$ の研究，物筫移動に対する Surface aeration の影

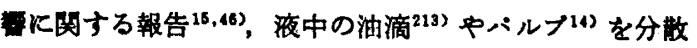
させたときの容量俰数に関する報告がある。また撑拌基 近傍での物質移動が非常に速やかに進行することも報告 されている147,206)。

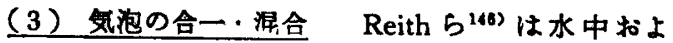
び電解質水溶液中での気泡の合一速度を二程の方法で测 定した。すなわち，水中に $\mathrm{N}_{2}$ と $\mathrm{O}_{2}$ を別々に吹き込み， 棤壁付近括よび異付近での気泡内のガス組成分布より合 一速度を求めた。さらK $\mathrm{O}_{2}-\mathrm{Na}_{2} \mathrm{SO}_{3}$ 水客液系の反応

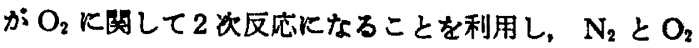
を予め混合して通気した场合と别々に通気した場合の反 応吸収速度の比から合一速度を計算した。その結果，水 中では電解質水溶液中上りも合一速度がはるかに大さい ことを見出した。ガスの滞留時間分布に関しては Gal一 
Or ら

\section{$3 \cdot 2$ 気泡塔}

気泡塔の特性については最近の総説 $64.65,103,105,155)$ ○ 参照されたい。

（1）ガスホールドフッブと気液界面䆄 ガスの空 塔速度 $u_{g}$ が小さいときは均一下分散した気泡が夜中を 上昇するが， $u_{0}$ が大きくなると気泡により液は港乱状 態になり気泡が合一して大気泡が生成する。合一は液粘 度の增大に伴ない激しくなり23)，液中に奄解筫が存在す

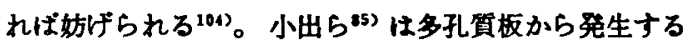
気泡の特性について研究している。高粘度夜中における 気泡の合一の理論的解析が行なわれている126)。

ガスホールドアップ $\varepsilon_{\mathrm{q}}$ は塔径 $D_{\mathrm{t}}$ が大きくなると $D_{\mathrm{t}}$ の影敏は無視できることが知られている。従来のデータ は恢田 ${ }^{155}$ により一括して図示されている。Hughmark ${ }^{83}$ は液物性値を考感した $\varepsilon_{0}$ K対する 相関図を提出してお ク, Mashelkar ${ }^{105)}$ は次式を提出した。

$$
\varepsilon_{q}=\left[u_{v} /\left(30+2 u_{q}\right)\right]\left(1 / \rho_{2}\right) /(72 / \sigma)^{1 / 3}
$$

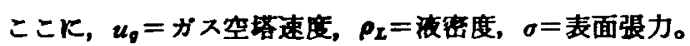

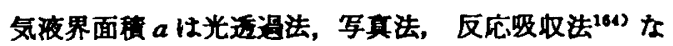
ぞにより测定されている40,144,166)が，测定者によってか なりの差がある145)。Abdel-Aal ら"は内径25インチの 塔で，液を 4 倕顉变えて光透過法に上り $a$ を即定し，相 闵式を得た。

\section{（2）物筫移重 反応受収法に上り気泡塔の液相容}

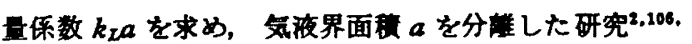
144,186) (少なくないが, Hughmark(1) は単一球表面にお ける物質移動に対する 半理詥式を Towell ら ${ }^{126)}$ のデー 夕に基つきき正している。Afschar ら"1並效気狍塔で $\mathrm{CO}_{2}$ の吸収実検を行ない，気液両相における $\mathrm{CO}_{2}$ の定

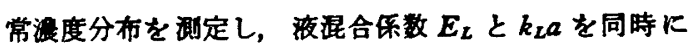
求めており，Coulon ${ }^{211}$ は周波数応答法による容量保数 测定法について述べている。

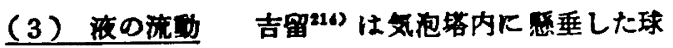
形の浮子に対する抵抗力より見措けの平均液速度を测定 した結果，塔中心部では上年流か，塔壁近傍では下向流 が裙められ，中心部の液速度 $v_{s 0}$ はガス流速 $u_{\sigma}$ K伴な い增大した。致傹乱流動城 $\left(u_{0}>6 \mathrm{~cm} / \mathrm{sec}\right)$ では $u_{0}{ }^{1 / 3}$ 下比例し，その值は気泡の平均上㫒速度 $u_{b}=u_{0} / \varepsilon_{0}$ K汪

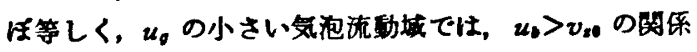
が成立している。宮内ら ${ }^{114)}$ はサンフリング法により局

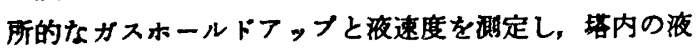
循理流は半径方向に存在するガスホールドフッブ分布に 伴5密度差飞よって引き起こされると考え, 液速度分布 式を求めている。Nevers $5^{123)}$ は夜循棵流时间的に変 動していることを锶察している。Freedman ら (5) は, ガス流速を增加していくとも。の增加率か減少する原因
は液循環流の発生にあると考え,ドラフトチューブを有 する気泡塔の $\varepsilon_{q}$ を理論的に算出する方法を提出し，そ れが擋乱流動域の気泡塔に適用できる可能性を示唆して

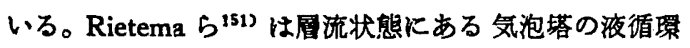
Кついて解析している。

（4）混合特性 気相における混合に関する研究は

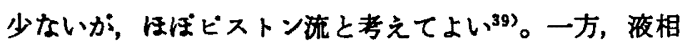
Кおける混合は塔径 $D_{\mathfrak{t}}$ 下依存し， $D_{\mathfrak{t}} か 37.7 \mathrm{~cm}$ 以下て

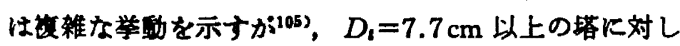
$\tau$, Reith $^{143)}$ は混合係数 $E_{L}$ 飞対する简単な相関式を得 ている。大朽 ${ }^{(26)}$ は低ガス流速の気泡流と高ガス流速 のスラッグ流に分け，前者に対しては Taylor 払散の理 論105) を通用し，後者については大気泡スラックにより 拡散距離が見措讨上長くなるとしたモデルを提出し，既 存の $E$ のデータを整理している。徐ら ${ }^{168)}$ す速度分布モ デルによる相関式を得ている。加藤ら ${ }^{80}$ 塔径 $6.6,12.2$ および $21.4 \mathrm{~cm}$ の 3 種類の塔における実测データおよび 既往の実悇結果 ${ }^{5,7.126 .143)}$ を整理して広籍囲に暗用できる 液混合俰数 $E_{L}$ に対する相関式を得ている。

樌田ら ${ }^{911}$ は必度が液に近い固体粒子をトレーサーに 選び，その軌跡を追跡した。粒子の軸方向变位は正規分 布で表現できることから, 液混合機構は払散現象に類似 していることを確認している。

気泡による夜混合は做しく，塔内部および熯壁におけ ろ伝熱は良好である。Fair ら (2,4) および Ruchenstein ら ${ }^{150)}$ は塔壁に括ける云熱保数に対する簡単な相関式を 得ている。

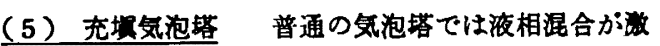
しく，反応収率向上の点からは不利であるので，塔を多 段化したり ${ }^{56.699}$ ，塔内部に充埧物を挿入して ${ }^{21,25)}$ ，液混 合を抑制しよ5と試みられている。Carleton ら21) は塔 径 $7.6 \sim 30.5 \mathrm{~cm}$ の向流気泡塔に $d_{p}=0.6 \sim 3.8 \mathrm{~cm}$ のラ シヒリンクをを充填したところ，环損失は若干剒加する か， $e_{g}, a$ および $k_{L}$ の值は普通の気泡塔に比效して增大 し，液相の湍留時間分布は㹟くなると報告している。久 保ら $\left.{ }^{80}\right)$ は気泡塔を多段化するとフラッディンクが起き中 すくなるか，ガスに供給と停止の一定サイクルをるつ脈 動を与えて操作特性の改善を陚みている。

（6）眎沟気泡塔 Narayanan 5 ${ }^{122)}$ は固体粒子の ナぺてが㷂河するに要する最低ガス流速を与える理論式 を導き，実検值との不一致を解消するため補正係数を導 入した。粒径の比校的小さな粒子が惄渴する场合には,

気泡の合一が促進され気液界面䅡は減少するか，奴液間

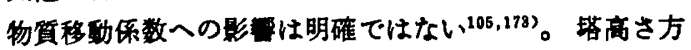

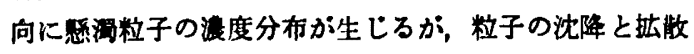
を同時に考虑したモデルKより粒子の混合係数が測定さ れている32,70,177, 2099。粒子坫よび夜の混合係数の間には 
レビะー

斦芯装圆」

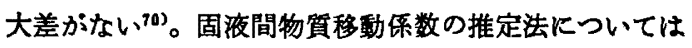
Satterfield ${ }^{161)}$ の成書を参照されたい。

\section{3 克顷 屏}

ここでは主に気液並流型の充塓層反応器に関する研究 を紹介する。ガス四収充埙塔については恩田らの総説 ${ }^{127)}$ を参照していただきたい。また，若尾ら ${ }^{198)}$ は㴖液型反 応器について解説している。

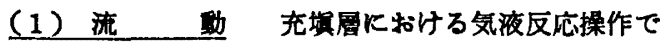
は筧度推進力上からは向流，並流の差がなくなり、フラ ッティンクの起らない並流操作がししろ有利になる ${ }^{203)}$ 。

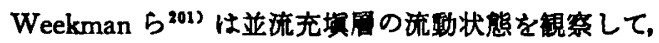
ガス流昷を一定に保ちながら液流旦を增加させると，液 が充填粒子表面を䀧状に流れるガス相連続流 (灌液流) から過渡領城を释て，ガスと液のスラッグが交互に流れ る脈動流へと変化することを示した。最近，Beimesh ら ${ }^{12)}$ は低ガス流量では脈县流のつぎにガスが気泡となっ て流下寸る液相連続流（気泡流）の領城か現われること を示し，脈動流飞対する流動モデルを提案している。 Prost ${ }^{100}$ 《眽動流の特性について詳細な実験的研究を発 表している。

並流充填首の圧力損失，ホールドアップに対する多く の相開か提出されている62,92, 142,149,178, 187, 2011。

\section{（2）物犋移動 Gianetto 555 は反応吸収法を用} いて下向並流充埧層の容量係数ならびに気液界面積 $a$ を 刷定した。気液流量が大になると，aの值は充填物表面 䅡 $a_{p}$ よりる大きくなり，aの最大値は $a_{p}$ の $180 \%$ とす 達する。彼らは液分散過程と消散エネルギー（圧力損 失， $-\Delta p / \Delta z)$ との関係に着目しつぎの相関式を得た。

$a / a_{p}=[0.81 \pm 0.02]\left[-(\Delta p / \Delta z) \cdot \varepsilon / a_{p}\right]^{0.48 \pm 0.01}$

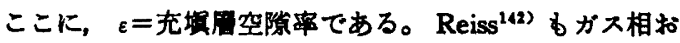
よび液相容量俰数と各相における王力强失との間に相関 を認めてお $\eta ， \quad k_{L} a$ は $\left[(-\Delta p / \Delta z) \cdot \varepsilon_{t}\right]$ の0.5 乘に比例 すると報告している。をは夜ホールドフ,ブである。

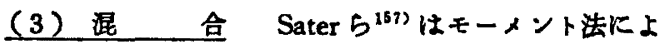

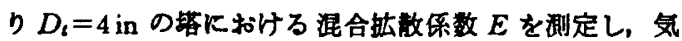
液両相のベクレ数に対する相関式を得た。Furzer ら (9), Co 5 ${ }^{28)}$ はパルス応答曲線に現われるテーリンクのため にモーメント法から算出される $E$ の值は実際よりす大 きく評価される危険性を举げて，パス応答曲線に一致 ナるよ5KEの值を決定している。二相流の場合の液 混合俰数は単相流のそれよりも大きい。

Hoogendoorn $5^{(7)}$, Swaaij $5^{178)}$ は充㙋周の一部に液 の停滞部の存在を認め，液流通相之液停滞部の間に物犋 の交換が起こるとするモデル（cross-flow model）を提 出し，交換係数の值を測定している。Villermaux ら ${ }^{195)}$

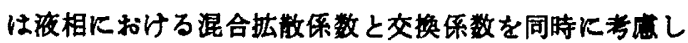
た一甪䙓雑なモデルを提出している。Hochman ら
下向並流充埧層の混合特性を拡散モデルと cross-flow model により整理したところ，後者による方がハルス応 答曲線を精度よく再現できると報告している。Heilmann $5^{62)}$ は上向並流充垣層における液混合係数の相関式を得

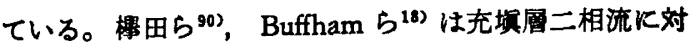
して確率的なモデルを提出している。Mears ${ }^{111}$ 注灌液 充埙層反応器の反応成䍃に対する混合払散の影㗽につい て考察している。

(4) 会 熱 Weekman 5 ${ }^{202)}$ は並流充埧展 の半径方向有効熱伝蔯度を単相流における矢木，国井の 式と類似の式で整理し，さらに脈動流領域についてはハ ルスの周期から接触時間を算出し，浸透説に従って管壁 における云熱俰数を計算し実臨值と比較している。

\section{$3 \cdot 4$ 三相流缜}

Ostergaard ${ }^{132,135)}$ は三相流動層に関する系統的な総説 を発表しているので䏍照されたい。加藤 ${ }^{7 n}$ の総説 む発表 されている。

（1）気泡の合一・分裂 Massimilla $5^{1072}$ は粒子 径 $d_{p}=0.22 \sim 1.1 \mathrm{~mm}$ の粒子を用いた三相流動層におけ る気泡径を写真振影して, 気泡の合一は屡下部において ほとんど完了し，層膨張に伴い減少することを示した。 $\emptyset_{\text {stergaard }}{ }^{131)}$ ○ $d_{p}=0.64 \mathrm{~mm}$ の砂粒子を用い同様な結 果を得ている。一方，Lee ${ }^{983}$ は $d_{p}=6 \mathrm{~mm}$ のガラス粒子 を流動化させて，平均気泡径と気液界面積を測定したと ころ，居上部での気泡径は屏下部に比較して小さくなっ ており，気泡上㫒に伴い気泡の分裂が起こっていること を確認した。ⓢtergaard ${ }^{125)}$ は空気(一水ーガラス粒子系の 三相流動展においては， $d_{2}=1 \mathrm{~mm}$ 以下では気泡の合一 が影著であるが， $d_{p}=6 \mathrm{~mm}$ の粒子では気泡の分裂が支 配的になり，小気泡か発生することを示した。

Lee ${ }^{95)}$ は粒子の情性力が液の表面張力に打勝つ塔合に 知の分裂が起こると考え，次式を提出している。

$$
W e_{p}=\rho_{p} u_{0}^{2} d_{p} / \sigma \geqq 3
$$

ここK, $\rho_{p}=$ 粒子密度, $u_{b}=$ 気泡上昇速度, $d_{p}=$ 粒子 径, $W e_{\mathrm{p}}=$ 臨界 Weber 数である。 Mach ${ }^{102)}$ は別の式を 提出しているか，気泡の分裂に対する液粘度の影唧は小 さいと報告している。Rigby ら ${ }^{153)}$ は三相流動㬝におけ る気泡の挙䣦につき詳細な研究を行ない，気泡上昨速度 に対する相成式を得ている。

（2）ホールドアッフ 液系流動層にガスを吹込む 之䊉子周高か减少する現象が知られている ${ }^{130) 。 S t e w a r t ~}$ $5^{176)}$ は二次元流動層による锶察を基にして, 三相流動 層は気泡相, 気泡後部に同伴される液相(ウェイク相)と 液流動相の三相から成立し, ウェイク相の速度は液流的 相の速度よりる速いために粒子を流動させる液速度の娍 少をまねきこれが周高隇少の原因になると推論した。

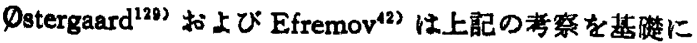


した流動モデルを展開し，Rigby ら ${ }^{152)}$ は気泡通過に伴 って戣生する渦を考虙したモデルを提出している。

粒子经，粒子密度が大きくなると層高膨張が起こ ろ $^{333}$ 。 Østergaard ${ }^{135)}$ はその原因をつきのように考えて いる。液流動相における速度減少はウェイク相の特性に 依存するか，第一近似として速度減少は粒子径变化に無 関係だとすると，液流動相の液速度の絶対值は粒径の增 加に伴い急激に增大し，ウェイク相の存在に起因する夜 速度の減少量には影需されなくなり，最早中周高減少は

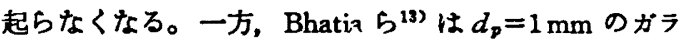
ス粒子表面をテフロンでコーテンクして水をはしくよ らにすると層高減少は起らなかったことから，粒子の

Wettability が重要な因子であると推論している。

三相流動層のガス，液および固相のホールドフッブに ついては, 上部の他にいくつかの研究 ${ }^{111,129.196)}$ が発表 されている。

(3) 湦 合 Michelsen $5^{113)}$ は直径 $15.2 \mathrm{~cm}$, 高さ $11 \mathrm{~m}$ の塔を用い，空氛一水一ガラス球粒子系につい てホールドフっブおよび気液両相の混合保数を不完全ハ ルス庍答法 ${ }^{133}$ Кより洞定した。粒子经 $d_{p}=3,6 \mathrm{~mm}$ の
大粒子では気泡分裂が支配的な領域に入り，小気泡が発 生しガスホールドフップ $\varepsilon_{q}$ は粒子が存在しない場合よ りす增大し, 液相混合は弱められる。 $d_{p}=1 \mathrm{~mm}$ のとき は, 気泡の合一が促進され $\varepsilon_{0}$ は減少し, 液混合係数 $E_{L}$ は增大する。ガス相の混合係数 $E_{\sigma}$ の正確な值は測定で きなかったか， $E_{a}$ は $E_{L}$ に比較して小さく，粒子径に 対する挙動は液相の场合と同様であった。一方, Vail $5^{188)}$ は定常法により $E_{\text {L }}$ の值を求めている。

(4) 気液閏物算移動 Østergaard $5^{1812}$ は $D_{t}=10$ $\mathrm{cm}$ の三相流陲屏で炭酸ガスの物理吸収実験を行ない， 気葆両相をビストン流と仮定して見掛けの夜相容量係数 $k_{L} a$ を测定した。気泡塔と比較して, $d_{p}=6 \mathrm{~mm}$ のガラ ス粒子を流動化させたときの $k_{L} a$ は大きく， $d_{p}=1 \mathrm{~mm}$ の場合には逆に小さくなった。 $k_{x} a$ の增減の主原因が気 液界面積aにあると考光ると，この現象は（1）で述へ た気泡の合一・分裂との関係から理解できよう。

Viswanathan ら ${ }^{196)}$ は層壁における层第係数を測定し た。低液流速の場合にはガス吹込みにより云熱俰数滥 著な增大を示すが，高液流速になるとそのよらな効果は 認められなくなった。

\section{引用文 城}

1) Abdel-Aal, H.K. G.B. Stiles and C.D. Holland : A. I. Ch. E. J., 12, 174 (1966)

2) Afschar, A.S., M. Diboun and K. Schugerl : Chem. Eng. $\mathrm{Sci}_{3}, 23,253$ (1968)

3) Akehata, T. and A. L. Johnson : Car. J. Chom Eng, 43, 262 (1965)

4) Albright, L.P. : Chem. Eng, Sept, 11, 197 (1967), Oct., 8, 249 (1967)

5) Aoyams, Y, K. Ogushi, K. Koide and H. Kubota: J. Chem. Eng. Japan. 1, 158 (1968)

6) 新㚼, 大井：工化棝, 74, 2276 (1971)

7) Argo, W.B. and D.R. Cova: Ind. Eng. Chem., Process Des. Develop, 4, 352 (1965)

8) 㱜田: 化学工学, 33, 736 (1969)

9) Astarita, G.: “Mass Transfer with Chemical Reaction”, Elsevier (1967)

10) Balasubramanian, S. N. D.N. Rihani and L.K. Draiswa. my: Ind. Eng. Chem., Fundamentals, 5, 184 (1966)

11) Barron, C. H. and H. A. O'Hern : Chem. Eng. Sci, 21, 397 (1966)

12) Beimesh, W.E. and D.P. Keseler: A. I. Ch. E. J, 17, 1160 (1971)

13) Bhatia, V.K., A. Evans and N. Epstein: Ind. Eng. Chem, Process Des. Develop. 11, 151 (1972)

14) Blakebrough, N. : Brit. Chem. Eng, 12, 78 (1967)

15) Boerma, H. and J. H. Lankester : Cherm Eng. Sci, 23, 799 (1968)

16) Bridgwater, J. : ibid, 22, 186 (1967)

17) Bridgwater, J. and J. J. Carberry : Brit. Chem. Eng., 12, 58,217 (1967)

18) Buffham, B. A, L.G. Gibilaro and M.N. Rathor: A. I. Ch. E. J, 18, 218 (1970)

19) Calderbank, P. H. and M. B. Moo-Young : Chem. Eng. Sci., 18, 39 (1961)

20) Calderbank, P.H., F. Evans, R. Farley, G. Jepeon and A. Poll: "Catalysis in Prectice", p.66 (London: Instn
Chem. Engra) (1963)

21) Calderbank, P.H. : "Mixing", Volume 2 (Uhl, V. W. and J.B. Gray eds.), p. 1, Academic Press (1967)

22) Calderbank, P.H.: The Chemical Engineer, No.212, CE 209 (1967)

23) Calderbank, P.H., M. B. Moo-Young and R. Bibby : Proc. 3 rd European Symp. Chem. React. Eng, p.91, Pergamon (1969)

24) Carleton, A. J., R. J. Flain, J. Rennie and F.H.H. Valentin : Chem. Eng. Sci, 22, 1839 (1967)

25) Chen, B.H. and R. Vallabh: Ind. Eng. Chem, Process Des. Develop, 9. 121 (1970)

26) Cichy, P.T, J.S. Ultmen and T. W.F. Russel: Ind. Eng. Chem, 61 (8), 6 (1969)

27) Cichy, P.T. and T.W.F. Russell : ibid., B1 (8), 15 (1969)

28) Co, P. and R. Bibaud : Can. J. Chem. Eng., 19, 727 (1971)

29) Coenen, J. W.E., H. Boerma, B.G. Linsen and B. de Vries : Proc. of 3 rd Congress on Catalyois, p. 1387, North-Hol. land (1965)

30) Cooper, C.M. G. A. Fernstrom and S. A. Miller: Ind. Eng. Chem., 30, 504 (1944)

31) Coulon, G. : Chemie-Ing.-Techn, 43, 280 (1971)

32) Cove, D.R. : Ind. Eng. Chem., Process Des. Develop., 5, 20 (1966)

33) Dakshinamurty, P. V. Subrahamanyam and J.N. Rao: Ind. Eng. Chem., Process Des. Develop, 10, 332 (1971)

34) Danckwerts, P.V.: "Gas-Liquid Reactions", McGrawHill (1970)

35) Danckwerts, P.V. and M.M. Sharma: The Chemical Engineer. No. 202, 244 (1966)

36) Date, R.V. J.B. Butt and H. Bliss: Ind. Eng. Chem, Fundamentals, 8, 687 (1969)

37) Desai, N.R. and D.S. Viswanath: Ind. Eng. Chem., Fundamentals, 11, 26 (1972)

38) De Waal, K.J.A. and J.C. Okeson: Chem. Eng. Sri, 21, 559 (1966) 
39) Diboun, M. and K. Schagerl : ibid., 22, 147 (1967)

40) Dierendonck, L. L. van, J.M.H. Fortuin and D. Vender bos: Proc. 4 th European Symp. Chem. React. Eng., p. 205, Pergamon (1971)

41) Dovell, F.S, W. E. Ferguson and H. Greenfield: Ind. Eng. Chem., Process Des. Develop., 9, 224 (1970)

42) Efremov, G.I. and I.A. Vakhrushev: International Chem. Eng, 10, 37 (1970)

43) Fair, J.R., A.J. Lambright and J.W. Andersen: Ind. Eng. Chem, Process Des. Develop. 1, 33 (1962)

44) Fair, J.R. : Chem. Eng, July 3, 67 (1967), July 17, 207 (1967)

45) Freedman, W. and J.F. Davidson: Trans. Instn Chem. Engrs, 17, T 251 (1969)

46) Fuchs, R, D.D. Y. Ryu and A.E. Humphrey: Ind. Eng. Chem. Process Des. Develop., 10, 190 (1971)

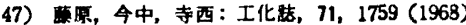

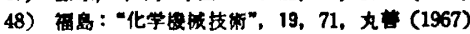

49) Furzer, I. A. and R.W. Michell : A. I. Ch. E. J., 16, 380 (1970)

50) Gal.Or, B. and W. Resnick : Chem. Eng. Sci., 19, 653(1964)

51) Gal.Or, B. and W. Resnick : Ind. Eng.Chem, Process Des. Develop, 5, 15 (1966)

52) Gal-Or, B. and H.E. Hoelscher: A. I. Ch. E. J., 12, 499 (1966)

53) Gal.Or, B. : Int. J. Heat Mass Transfer, 11, 551 (1968)

54) Gehlawat, J.K. and M. M. Sharma : Chem. Eng. Sci, 19, 653 (1968)

55) Gianetto, A, G. Baldi and V.Specchia : Ingegnere Chimico Italiano, 6, 125 (1970)

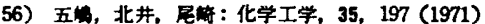

57) Harriott, P. : Can. J. Chem. Eng., 48, 109 (1970)

58) Hashimoto, K, M. Teramoto, T. Nagayasu and S. Nagata: J. Chem. Eng. Japan, 1, 132 (1968)

59) Hashimoto, K, K. Muroyama and S. Nagata : J. Am. Oil Chemist' Soc, 48, 291 (1971)

C0) Hashimoto, K., M. Teramoto and S. Nagata : J. Chem. Eng. Japan, 4, 150 (1971)

61) Hattori, K., Y. Tanaka, H. Suzuki, T. Ikawa and H. Kubota : ibid, 3, 72 (1970)

62) Heilmann, von W. and H. Hofmann : Proc. 4th European Symp. Chem. React. Eng. p.167, Pergamon (1971)

63) Hewitt, G.F. and N.S. Hall-Taylor: "Annular TwoPhase Flow", Pergamon (1970)

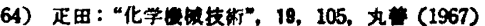

65) 足田, 石川：化学工年, 33, 729 (1969)

66) Hochman, J. M. and E. Effron : Ind. Eng. Chem., Funda. mentals, 8, 63 (1969)

67) Hoogendoorn, C. J. and J. Lips : Car. J. Chem. Eng, 43, 125 (1965)

68) Hughmark, G. A. : Ind. Eng. Chem., Process Des. Develop. 8, 218 (1967)

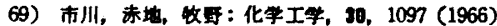

70) Imafuku, K. T.Y. Wang, K. Koide and H. Kubota : J. Chem: Eng. Japan, 1, 153 (1968)

71）今中, 松本, 䏦村, 寺西：工化等，74，1071 (1971)

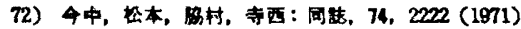

73) Inoue, H. and T. Kobayashi : Proc. 4 th European Symp. Chem. React. Eng., p.147, Pergamon (1971)

74) Ishimoto, S., T. Sasano and K. Kawamura: Ind. Eng. Chem., Process Des. Develop., 7, 469 (1968)

75) Jhaveri, A.S. and M. M. Sharma: Chem. Eng. Sci, 22, 1 (1967)

76) Jhaveri, A.S. and M.M. Sharma: ibid., 23, 1 (1968)

77) 加滕闻：化学工学, 34, 1272 (1970)

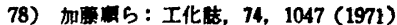

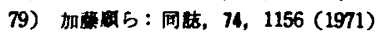

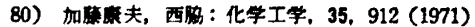

81) Kawecki, W., T. Reith. J. W. van Heuven and W. J. Beek : Chem. Eng. Sci., 22, 1519 (1967)

82) King, C.J.: Ind. Eng. Chem. Fundamentals, 5, 1 (1966)

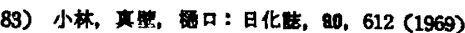

84) 小出, 久保田, 進青: 化学工学, 28, 657 (1964)

85) Koide. K., S. Kato, Y. Tanaka and H. Kubota : J. Chem. Eng. Japan, 1, 51 (1968)

86) Kolbel, H., T. Matsuura and H. Hammer: Chemie-Ing.Techn., 42, 1149 (1970)

87) Kolbel, H. D. Klotzer and H. Hammer: ibid, 48, 103 (1971)

88) Kolbel, H. and M. Ulrich : ibid, 43, 609 (1971)

89）久保，甲定，宫内：化学工学，34，856 (1970)

90) 田, 大竹: 化学工学, 30, 144 (1966)

91) Kunugita, E, M. Ikura and T. Otake: J. Chem. Eng. Japan, 3, 24 (1970)

92) Larkins, R.P., R.R. White and D.W. Jeffrey: A. I. Ch. E. J, 7, 231 (1961)

93) Lee, J.C.: Proc. 3 rd European Symp. Chem. React. Eng. p. 211, Pergamon (1969)

94) Lee, J.C. and D. L. Meyrick : Trans. Instn Chem. Engrs, 48. T 37 (1970)

95) Lee, J.C.: Proc. 4 th European Symp. Chem. React. Eng. p.27, Pergamon (1971)

96) Linek, V. : Chem. Eng. Sci., 21, 777 (1966)

97) Linek, V. and J. Mayrhoferová : ibid., 24, 481 (1969)

98) Linek, V. and J. Mayrhoferova : ibid., 25, 787 (1970)

99) Linek, V, J. Mayrhoferová and J. Mołnerová : ibid, 25, 1033 (1970)

100) Linek, V. and J. Mayrhoferová : ibid, 26, 1319 (1971)

101) Linek, V. and J. Trrdik: Biotechnol. Bioeng 13,353 (1971)

102) Mach, W.: Chemie-Ing.-Techn, 42, 311 (1970)

103）首田, 只木：化学工学, 30, 474 (1966)

104) Marrucci, G. and L. Nicodemo: Chem. Eng. Sci, 22, 1257 (1967)

105) Marshelkar, R. A. : Brit. Chem. Eng., 15, 1297 (1970)

106) Marshelkar, R. A. and M. M. Sharma : Trans. Instn Chem. Engrs, 48, T 162 (1970)

107) Massimilla, L., A. Solimando and E. Squillace: Brit. Chem. Eng, 6, 232 (1961)

108）松本，4中, 寺西: 工化浲，72，1219 (1969)

109）望本，4中，寺西：同结，73，652 (1970)，74，1298 (1971)

110) Matsuura, A, J. Harada, T. Akehata and T. Shirai : J. Chem. Eng. Japan, 2, 199 (1969)

111) Mears, D.E. : Chem. Eng. Sci., 26, 1361 (1971)

112) Mehta, V.D. and M.M. Sharma: ibid., 26, 461 (1971)

113) Michelsen, M.L. and K. Ostergaard: Chem. Eng. J. 1, 37 (1970)

114）它内, 除: 化学工年, 34, 958 (1970)

115) Miyauchi, T, T. Kikuchi, T, Ogoshi, R. Susuki and K. Kataoka : J. Chem. Eng. Japan, 4, 44 (1971)

116) *田：化䋃工学, 34, 126 (1970)

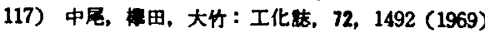

118）中层、田、大竹：化学工学, 32, 285 (1968)

119）中尾, 掼田, 大仂: 同然, 33, 202 (1969)

120）中尾, 枟本, 大竹：工化誌，72，1880 (1969)

121）中层, 昖本, 大竹：化学工学, 36, 86 (1972)

122) Narayanan, S, V.K. Bhatia and D.K. Guha: Can, J. Chem. Eng., 41, 360 (1969)

123) Nevers, N. de : A. I. Ch. E. J., 14, 222 (1968)

12A) Nevers, N. de and J.L. Wu : ibid, 17, 182 (1971)

125) Ohki, Y. and H. Inoue: Can. J. Chem. Eng., 47,576 (1969)

126) Ohki, $Y$. and $H$. Inoue : Chem. Eng. Sci, 25, 1 (1970)

127) 息田, 竹内：化学工学, 33, 724 (1969)

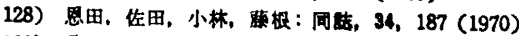

129) Østergaard, K. : Chem. Eng. Sci, 20, 165 (1965)

130) Østergaard, K. and P.I. Theisen : ibid, 21, 413 (1966)

131) Østergaard, K. : ibid., 21, 470 (1966)

132) Østergaard, K. : "Advances in Chemical Engineering", Vol. 7. p.71, Academic Press (1968)

133) Ostergand, K. and M. L. Michelsen: Can. J. Chem. Eng, 47, 107 (1969)

134) Ostergaard, K. and W.Suchozebraki: Proe. 4th European 
Symp. Chem. React. Eng, p. 21, Pergamon Press (1971)

135) Østergaard, K : "Fluidization", (J.F. Davidson and D. Harrison eds.) p. 751, Academic Press (1971)

136）大竹, 中田，化学工学, 31, 691 (1967)

137) Pavlica, R.T. and J.H. Olson: Ind. Eng. Chem., 62 (12), 45 (1970)

138) Prengle H.W. Jr. and N. Barona: Hydrocarbon Processing, March, 106 (1970)

139) Prengle H.W.Jr. and N. Barona : ibid. Nov, 159 (1970)

140) Prost, C.: Chem. Eng. Sci, 22, 1283 (1967)

141) Pruden, B. B. and M.E. Weber : Can. J. Chem. Eng, 48, 162 (1970)

142) Reiss, L. P. : Ind. Eng. Chem, Process Des. Develop, 6, 486 (1967)

143) Reith, T, S. Renken and B.A. Israel : Chem. Eng. Sci, 23, 619 (1968)

144) Reith, T. and W.J. Beek: Proc. 4th European Symp. Chem. React. Eng, p. 191, Pergamon (1970)

145) Reith, T. : Brit. Chem. Eng, 15, 1559 (1970)

146) Reith, T. and W.J. Beek: Trans. Instn Chem. Engrs, 48, T 63 (1970)

147) Rennie, J. and F.H.H. Valentin: Chem. Eng. Sci, 23, 663 (1968)

148) Resnick, W. and B. Gal-Or: "Advances in Chemical Engineering", Vol. 7, p. 295, Academic Press (1968)

149) Reynier, J.P. and J.C. Charpentier: Chem. Eng. Sci, 26, 1781 (1971)

150) Rhodes, E. and D.S. Scott: "Cocurrent Gas-Liquid Flow", Plenum Press (1969)

151) Rietema, K. and S.P.P. Ottengraf : Trans. Insen Chem. Engrs, 4, T 54 (1970)

152) Rigby, G.R and C.E. Capes: Can. J. Chem. Eng, 48, 343 (1970)

153) Rigby, G.R., G.P. van Blockland, W.H. Park and C.E. Capes: Chem. Eng. Sai, 25, 1729 (1970)

154) Ruckenstein, E. and O. Smigelschi : Trans. Instn Chem. Engrs, 43, T 334 (1965)

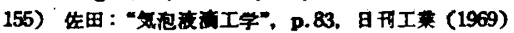

156）佐田：“最近の化学工学”, 1968 年, p.25, 丸荃 (1968)

157) Sater, V.E. and O. Levenspiel : Ind. Eng. Chem, Funda. mentals, 5, 86 (1966)

158）佐電, 中尾, 大竹: 化学工学, 34, 505 (1970)

159) Satterfield, C.N, Y. H. Ma and T. K. Sherwood: Inst. Chem. Engrs. Symp. Ser, No.28, 22 London (1968)

160) Satterfield, C.N, A.A. Pelossof and T.K. Sherwood: A. I. Ch. E. J, 15, 226 (1969)

161) Satterfield, C.N. : "Mass Transfer in Heterogeneous Catalysis", M.I.T. Press (1970)

162) Schaftlein, R.W. and T.W.F. Russell : Ind. Eng. Chem. 60 (5), 12 (1968)

163) Schoon, N.H. et al. : Acta Polytech. Scand. Chem. incl. Met. Ser, 100.1, 100.2, 100.3, 100.4, 100.5, Stockholm (Roy. Swed. Ac. of Eng. Sci.) (1971)

164) Sharma, M.M and P.V. Danckwerts : Brit. Chem. Eng. 15, 522 (1970)

165) Sherwood, T.K. and E.J. Farkas: Chem Eng. Sci, 21, 573 (1966)

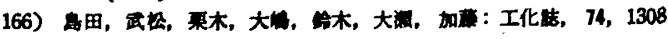
(1971)

167）消水，井上，西方，肥沼，竹村，相次，小林，江木，经本，若尾： 化学工学, 34, 193 (1970)

168）徐, 宫内: 同殸, 35, 663 (1971)

169) Sideman, $S_{\eta}$ O. Hortacsu and J.W. Fulton: Ind. Eng. Chem. 58 (7), 33 (1966)

170) Silberstein, B., J. B. Butt and H. Bliss : Ind. Eng. Chem. Process Des. Develop, 8, 221 (1969)

171) Silberstein, B, H. Bliss and J.B. Butt: Ind. Eng. Chemn Fundamentals, 8, 366 (1969)

172) Sleswer, C.G.M. and J. Hight: Bvis. Chem. Eng, 11, 247 (1966)

173) Slesser, C.G.M., W.T. Allen, A.R. Cumming, U. Pawl- owsky and J. Shields: Proc, 4 th European Symp. Chem. React. Eng., p. 41, Pergamon (1971)

174) Smith, J.M.: "Chemical Engineering Kinetics", 2nd Ed, p. 383, McGraw-Hill (1970)

175) Srivastava, R.D., A.F. McMillan and I. J. Harris : Can. J. Chem. Eng., 46, 181 (1968)

176) Stewart, P.S.B. and J.F. Davidson: Chem. Eng. Sci, 19, 319 (1964)

177) 昔沼, 山晒: 化学工学, 30, 1136 (1966)

178) Swaaij, W.P.M. van., J.C. Charpentier and J. Villermaux : Chem. Eng. Sci, 24. 1083 (1969)

179) Sweeney, D.E.: A. I. Ch. E. J, 13, 663 (1967)

180) Srekely, J. and J. Bridgwater: Chem. Eng. Sci, 22, 711 (1967)

181) 田中: 化学工学, 34, 1265 (1970)

182) Tavlarides, $L$, C.A. Coulaloglou, M. A. Zeitlin, G.E. Klinzing and B. Gal-Or: Ind. Eng. Chem, 62 (11), 6 (1970)

183) Teramoto, $M_{*}$, T. Nagayasu, T. Matsui, K. Hashimoto and S. Nagate: J. Chem. Eng. Japan, 2, 186 (1969)

184) Teramoto, M., S. Fujita, M. Kataoka, K. Hashimoto and S. Nagata : ibid., 3, 79 (1970)

185) Tichacek, L. J., C. H. Barkelew and T. Barron: A. I. Ch. E. J. 3, 439 (1957)

186) Towell, G.D. C.P. Strand and C.H. Ackerman : A. I. Ch, E.-I. Chem. E. Symp. Ser, No. 10, 97 (1965)

187) Turpin, J.L. and R.L. Huntington: A. I.Ch.E.J, 13, 1196 (1967)

188) Vail, Y.K. N.K. Manakov and V.V. Manshilin: Int. Chem. Eng, 8, 516 (1968)

189) Vail, Y.K, N.K. Manakov and V.V. Manshilin: ibid, 10,244 (1970)

190) Van Deemter, J.J. : Proc. 3rd European Symp. Chem. React. Eng., p. 215, Pergamon (1969)

191) van de Vusse, J.G. : Chem. Eng. Sci., 21, 631, 645 (1966)

192) van de Vusse, J.G. : ibid., 21, 1239 (1966)

193) Valentin, F.H.H. : Brit. Chem. Eng, 12, 1213 (1967)

194) Venugopal, B., R. Kumar and N.R. Kuloor: Ind. Eng. Chem., Process Des. Develop., 8, 139 (1967)

195) Villermaux, J. and W.P.M. van Swaaij: Chem. Eng. Sci, 24, 1097 (1969)

196) Viswanathan, S., A.S. Kakar and P.S. Murti : ibid., 20, 903 (1964)

197) Volpicelli, G. and L. Massimilla : ibid., 25, 1361 (1970)

198) 若尾, 江木: 化学工学, 34, 1260 (1970)

199) Wallis, G.B.: "One Dimensional Two-Phase Flow", McGraw-Hill (1969)

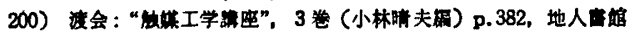
(1965)

201) Weekman, V.W. Jr. and J.E. Myers : A. I. Ch. E. J., 10, 951 (1964)

202) Weekman, V.W.Jr. and J.E. Myers : ibid., 11, 13 (1965)

203) Wen, C.Y. W.S. O'Brien and L. T. Fan: J. Chem. Eng. Data, B, 42 (1963)

204) Wesselingh, J.A. and A.C. van't Hoog: Trans. Instn Chem. Engrs, 48, T 69 (1970)

205) Westerterp, K. R, L.L. van Dierendonck and J.A. de Kraa : Chem. Eng. Sci., 18, 157 (1963)

206) Wilhelm, R.H., W.A. Donohue, D.J. Valesano and G. A. Brown : Biotechnol. Bioeng., 8, 55 (1966)

207) Wohler, F. and R. Steiner: Chemie-Ing.-Techn, 12, 481 (1970)

208) Yamaguchi, I., T. Oishi, N. Hashimoto and S. Nagata: Mem. Fac. Eng. Kyoto Univ., 27, 118 (1965)

209) Yamanaka, Y, T. Sekizawa and H. Kubota: J. Chem. Eng. Japan, 3, 264 (1970)

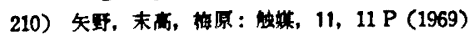

211）吉田, 大竹, 中居: 化学工学, 30, 460 (1966)

212) Yoshida, F. and S. Arakawa: A. I. Ch. E. J., 14, 962 (1968)

213) Yoshida, F, T. Yamane and Y. Miyamoto: Ind. Eng. 
レビニー「反芯相」

Chem. Process Des. Develop., 9, 570 (1970)

214) Yoshitome, H. and T. Shirai : J. Chem. Eng. Japan, 3, 29
(1970)

215) Zlokenik, M. : Chemie-Ing.-Techn., 38, 717 (1966)

\section{5. 重合 反応装置*}

大島栄次**

\section{1.はじめに}

重合反応工学といら名称が网かれるよらになってから 少なくとあ 5 年は秚っているが，重合反応のための反応 装圈の設計に対する指針は未たに体系的にまとめられて いるとは言えない状態である。その原因は反応機棈が襩 雑であること，製品に対して要求される仕様が弾しいこ と, とくに不粁物の混入，物性の不均一性などが極端に きらわれること, 反応系内の液の粘度が通常の反応器の 条件と著しく異なることなどが考えられる。したがっ て,今まで開発されてきた反応装置す当面する問題点 を解決するために思いついた工夫の域を眖しないるのが 少なくない。

あちろん，新しく生まれたり，改良されたりする装監 の恐らく大部分は，释㯺に基ついた思いつきや工夫に端 を発しているといらことができるが，装晨工学の立场か らはそれがどのような意味で合理的であるかを説明する 必要がある。そのためには重合反応の特微およびそれに

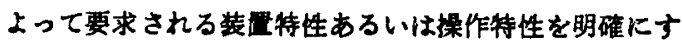
ることが重要である。重合の反応装目成する反応工学 的な問題点は大まがは混合と除熱の二つであるといえ

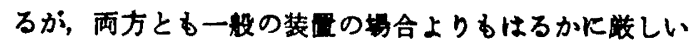
条件にあるといらことができる。

ここでは，重合反応の特殊性，および重合反応操作の 種類について概略を述へ，繶いて重合反応装圈の典型的 な例を幾つか示し，機能的な問題について多少の教察を 加えることにする。

\section{2. 五合反态の特微}

重合反応は一般に連銧反应機粠として説明されてい る。すなわち，活性中心を生成する開始反応，活性中心 がモノーを付加し活性中心自身の分子量を增大させる 生長反応，活性中心を他の分子へ枟移させる連鎖移動，

- 昭和 47 年 5 月 15 日受理

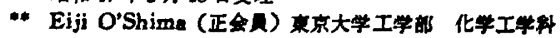

活性中心同志の反応火上り消娍する停止反応から成って いる。活性中心の典型的な例はラジカル重合におけるボ リマーラシシカルであるか，活性中心は反応性が高く不安 定であるために，開始反応により生成してから停止反応 に上って消娍するまでの寿命が非常に短かい。この事が 活性中心K対して定常状態法を通用することができる由 縁であある。この寿命の間にその活性中心がどれだけ生 長反応を綝返したかといらことが得られるポリマーの分 子量を决めることになり，モノマーの消費速度すなわち 反応速度を決定する直接の因子となる。

ラジカル重合を例にとると，一般に反応機粠はつぎの よらな素反応で表わされると考えられている゙。

$$
\begin{aligned}
& \text { 闰始反店 Cat } \stackrel{k_{d}}{\longrightarrow} R_{e} \text {. } \\
& R_{e} \cdot+M \stackrel{k_{i}}{\longrightarrow} R_{1} \cdot \\
& \text { 生長反店 } R_{1} \cdot+M \stackrel{k_{p}}{\longrightarrow} R_{2} \text {. } \\
& R_{i} \cdot+\stackrel{k_{7}}{\longrightarrow} R_{i+1} \text {. }
\end{aligned}
$$

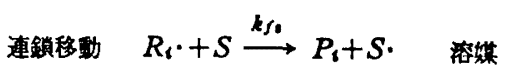

$$
\begin{aligned}
& R_{1} \cdot+M \stackrel{k_{f m}}{\longrightarrow} P_{t}+R_{1} \cdot \quad \text { モノフー } \\
& R_{\mathrm{i}} \cdot+P_{\mathrm{j}} \stackrel{\text { kfp }}{\longrightarrow} P_{\mathrm{l}}+R_{\mathrm{j}} \cdot \text { ポリマー } \\
& \text { 停止反応 } R_{i} \cdot+R_{j} \cdot \stackrel{k_{\mathrm{td}}}{\longrightarrow} P_{\mathrm{i}}+P_{\mathrm{j}} \quad \text { 不均斉化 } \\
& R_{i} \cdot+R_{j} \cdot \stackrel{k_{i r}}{\longrightarrow} P_{i+j} \quad \text { 再結合 }
\end{aligned}
$$

それぞれの反応速度定数は反応物の分子至 $i$ K依存し ないとすると，活性中心の瀑度の総和でまとめて取扱 5 ことができる。たとえば、モノマーの消䇾速度は上の反 応機粠の場合には次式で表わされる。

$$
\begin{aligned}
-\frac{d[M]}{d t}= & k_{\mathrm{v}}[M]\left[R_{\mathrm{c}} \cdot\right]+k_{\mathrm{p}}[M] \sum\left[R_{\mathrm{i}} \cdot\right] \\
& +k_{\mathrm{s}_{\mathrm{m}}}[M] \Sigma\left[R_{\mathrm{i}} \cdot\right]
\end{aligned}
$$

ここで，開始郕ラジカルの䈨度 $\left[R_{0} \cdot\right]$ 活性ボリマー 瀑度の総和 $\sum_{i}\left[R_{i} \cdot\right]$ K比へて非常に小さく， $k_{t}$ と $k_{p}$ と 仕同程度の值と考えられるので，第一顷は無視できると 